\title{
First record of Myocastor coypus (Molina 1782) (Mammalia, Rodentia) for the state of Mato Grosso do Sul, Brazil, and its distribution in southern South America
}

\author{
Primer registro de Myocastor coypus (Molina 1782) (Mammalia, Rodentia) para el estado de Mato \\ Grosso do Sul, Brasil y su distribución en el sur de Sudamérica
}

\author{
Rodney Murillo Peixoto-Couto ${ }^{1 *}$, Anderson Correa-Branco ${ }^{2,4}$, and Maiara Cabrera-Miguel ${ }^{3}$
}

\begin{abstract}
This study presents the first record of Myocastor coypus in the state of Mato Grosso do Sul, in addition to detailing its distribution within southern South America, highlighting where it is considered native or exotic in Brazil. On April 23, 2018, at approximately 18:00, an adult specimen with a $40 \mathrm{~cm}$ BL (body length) was registered after being run over on a side road near wetlands and a dam in a rural area in the municipality of Bataguassu, eastern state of Mato Grosso do Sul. It is not possible to state the origin of the M. coypus reported in the present study; whether it was introduced or dispersed naturally through the flooded areas of the Paraná River, since the species has records on the border of the states of Mato Grosso do Sul and Paraná.
\end{abstract}

Keywords: Expansion of distribution, exotic, nutria, coypu, South America

\section{Resumen}

Este estudio presenta el primer registro de Myocastor coypus en el estado de Mato Grosso do Sul, además de señalar su distribución al sur de América del Sur, destacando dónde se considera nativo y exótico en Brasil. El 23 de abril de 2018, aproximadamente a las 6:00 pm, se registró, con un LC (longitud corporal) de $40 \mathrm{~cm}$, un espécimen adulto atropellado en un camino lateral cerca de humedales y una represa, en un área rural en el municipio de Bataguassu, al este del estado de Mato Grosso do Sul. No es posible determinar el origen de M. coypus reportado en el presente estudio; tampoco es posible establecer si fue introducido o dispersado de forma natural por las zonas pantanosas del río Paraná, ya que la especie tiene registros en la frontera de los estados de Mato Grosso do Sul y Paraná.

Palabras claves: expansión de la distribución, exótico, nutria, coipo, Sudamérica

\footnotetext{
1. Faculdade de Ciências Biológicas e Ambientais, Universidade Federal da Grande Dourados, Brazil.

2. Programa de Pós-Graduação em Biologia Comparada e Grupo de Estudos em Ecologia de Mamíferos e Educação Ambiental (GEEMEA),

Universidade Estadual de Maringá, Maringá, Paraná, Brasil.

3. Instituto de Biociências, Universidade Federal de Mato Grosso do Sul, Campo Grande, Mato Grosso do Sul, Brazil.

4. Neotropical Institute, Research and Conservation. Curitiba, Paraná, Brazil

* Corresponding author: <couto.murillo@gmail.com>
} 
Myocastor coypus (coypu / nutria) is a rodent (Lacher et al., 2020; Patton et al., 2015) of the Myocastoridae family (Wilson and Reeder, 2005), an excellent swimmer which easily colonizes available habitats (Bueno, 2013). It is a large rodent 1$10 \mathrm{~kg}$ (Bonvicino et al., 2008; Paglia et al., 2012), body $40-60 \mathrm{~cm}$; tail $30-45 \mathrm{~cm}$ (Oliveira and Bonvicino, 2006), with dorsal yellowish-grey fur, streaked with black hair, the sides are lighter, the ventral region is whitish with a cylindrical tail (Oliveira and Bonvicino, 2006; Woods et al., 1992). Feet are much longer than hands, and contain five digits, four of which are connected by a membrane and the fifth is free (Oliveira and Bonvicino, 2006; Woods et al., 1992). Hands have four digits, long, flexible and free; the incisors are highlighted and bright orange yellow (unlike those in rats which are brown-yellow), with white marks on the muzzle (Bueno, 2013; Oliveira y Bonvicino, 2006; Woods et al., 1992). They are abundant in freshwater, brackish and saltwater marshes, but they may also live along lentic lakes and streams (Nowak, 1999), with a preference for humid areas with emerging vegetation and areas with succulent vegetation along the banks (Greer, 1966). Although they feed mainly on vegetable matter, they can occasionally prey on molluscs and the eggs of waterfowl (Angelici et al., 2012; Scaravelli, 2002).

The species is native from southern South America, occurring in Argentina, Bolivia, Chile, Paraguay, Uruguay, and southern Brazil (Guichón et al., 2003; Oliveira and Bonvicino, 2006; Woods et al., 1992). In Brazil, its original distribution includes the states of Rio Grande do Sul, Santa Catarina, and Paraná (Bavaresco et al., 2017; Bonvicino et al., 2007; Cherem et al., 2004; Moojen, 1952), but it has been introduced in other states, such as São Paulo (De Vivo et al., 2011), or dispersed to Rio de Janeiro (Bueno, 2013). The bathing rat was introduced in several countries around the world for the value of its skin and its meat, including Italy (Bertolino and Ingegno, 2009; Prigioni et al., 2005) and Great Britain (Harris, 1995), Finland and North America (Guichón et al., 2003), causing damage to the natural environment of the invaded areas (Genovesi et al., 2009). There are reports of the presence of this species also across Asia, including Japan, China, South Korea, and Thailand and in Africa (Kenya, Zimbabwe,
Zambia, and Botswana) (Carter and Leonard, 2002). Thus, M. coypus has been introduced on all continents, except Australia and Antarctica (Bueno, 2013) and on the Caribbean islands (Borroto-Páez and Woods, 2012). According to Woods et al. (1992), the species may have been introduced in certain regions of the world in the hope of reducing populations of undesirable aquatic plants.

The species is classified by the International Union for the Conservation of Nature (IUCN) as one of the 100 worst invasive alien species in the world, considered exotic in 44 countries (Global Invasive Species Database [GISD], 2020; Lowe et al., 2000). Among other impacts are its ability to compete for niches with native species, to destroy waterfowl nests in search of eggs (Angelici et al., 2012; Scaravelli, 2002), and due to their digging habits, to weaken and damage riverbanks (GISD, 2020; Guichón and Cassini, 2005). Also, according to Carter and Leonard (2002), they can feed on agricultural crops, including sugar cane, alfalfa, and other roots (Woods et al., 1992); in studies carried out in France and Brazil by Ménard et al. (2001) and El-Kouba et al. (2009), M. coypus is reported as a host of Fasciola hepatica. Howerth et al. (1994), studying a population of $M$. coypus in Louisiana (USA) registered Toxoplasma gondii, Chlamydua psittaci and Leptospira sp. serogroups.

On April 23, 2018, at approximately 18:00, an adult specimen with a $40 \mathrm{~cm}$ (figure 1) was recorded as being run over on a side road near wetlands and a dam in a rural area in the municipality of Bataguassu, east of the State of Mato Grosso do Sul (21 $44^{\prime} 28.46^{\prime \prime} \mathrm{S}$; $52^{\circ} 20^{\prime} 8^{\prime \prime} \mathrm{W}$ ) (figure 2 ). The region was originally composed of savannah vegetation (Cerrado sensu strictu and Cerradão) (Pott et al., 2014). The climate according to the Köppen classification is the humid tropical (Aw), characterized by two well-defined seasons of dry winters (April - September) and rainy summers (October - March), with annual precipitation ranging between 1400 and $1700 \mathrm{~mm}$, in which November, December and January are the rainiest months (Zavattini, 2009). The average temperature in the coldest month is over $18^{\circ} \mathrm{C}$ while the average annual maximum is between $27^{\circ} \mathrm{C}$ and $32^{\circ} \mathrm{C}$, with absolute maximum between $35^{\circ} \mathrm{C}$ and $40^{\circ} \mathrm{C}$ while the absolute minimum can reach $0^{\circ} \mathrm{C}$ (Oliveira et 
al., 2000; Walter, 2006). According to the Specialist Group on Invasive Species (ISSG), M. coypus, is one of the few mammal species that can be successfully considered invasive, present in forty-four countries (GISD, 2020). Considering the great capacity of dispersion and colonization of new habitats of $M$. coypus and in view of all the problems already presented, it is necessary to monitor this species in any new environments populated by it.

This study presents the first record of Myocastor coypus in the state of Mato Grosso do Sul and defined its distribution in the south of South America, highlighting where it is considered native or exotic within Brazil (table 1 and figure 2). This finding widens the distribution of Myocastor coypus in Brazil (figure 2). It is not known for certain which states (where it is non-native) the species arrived first. $M$. coypus is believed to have been introduced in the state of São Paulo due to the economic values related to its meat and skin (Bonvicino et al., 2007). For the other states, it is not known whether it was introduced, or the occupation occurred naturally.

It is not possible to state the origin of $M$. coypus reported in the present study, whether it was introduced or dispersed naturally in the swampy areas of the Paraná River, since the species has records on the border with the states of Mato Grosso do Sul and Paraná, where it is considered native, about $150 \mathrm{~km}$ from the record site (Aguiar et al., 2007). However, the record of an adult specimen may indicate the presence of other individual in the area and, considering the life cycle where sexual maturity varies between 3-10 months with a gestation of 127-138 days and with litters that vary of 5-13 pups (Oliveira and Bonvicino, 2006; Woods et al., 1992), has a great potential of becoming an invasive species in the state. It is necessary to implement monitoring programs to determine whether the species is present in the area,

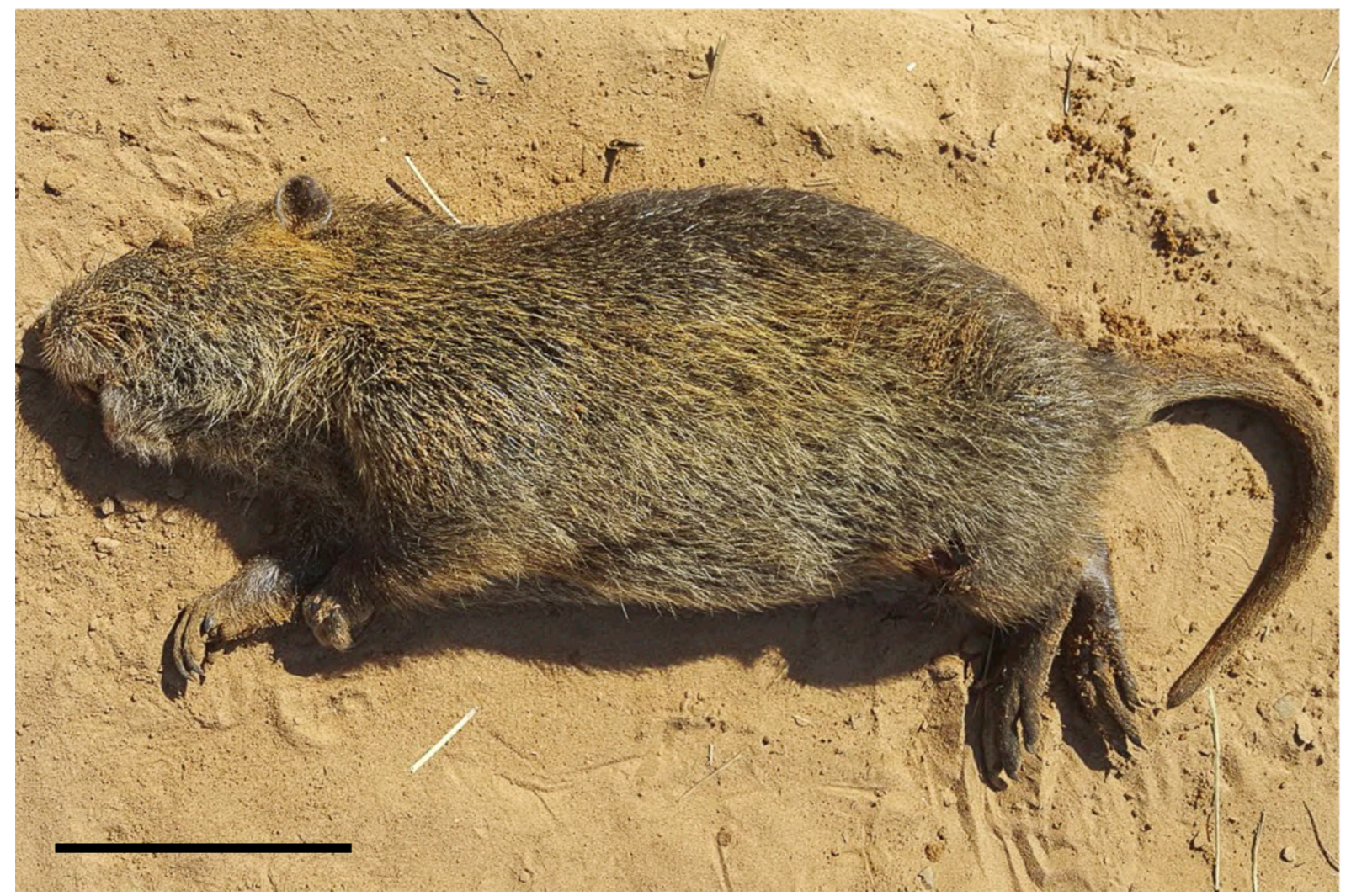

Figure 1. Myocastor coypus record being run-over and dead on a side road near wetlands and a dam, in a rural area in the municipality of Bataguassu ( $\left.21^{\circ} 44^{\prime} 28.46^{\prime \prime} \mathrm{S} ; 52^{\circ} 20^{\prime} 8^{\prime \prime} \mathrm{W}\right)$, east of the State of Mato Grosso do Sul, Brazil (10 cm bar). 


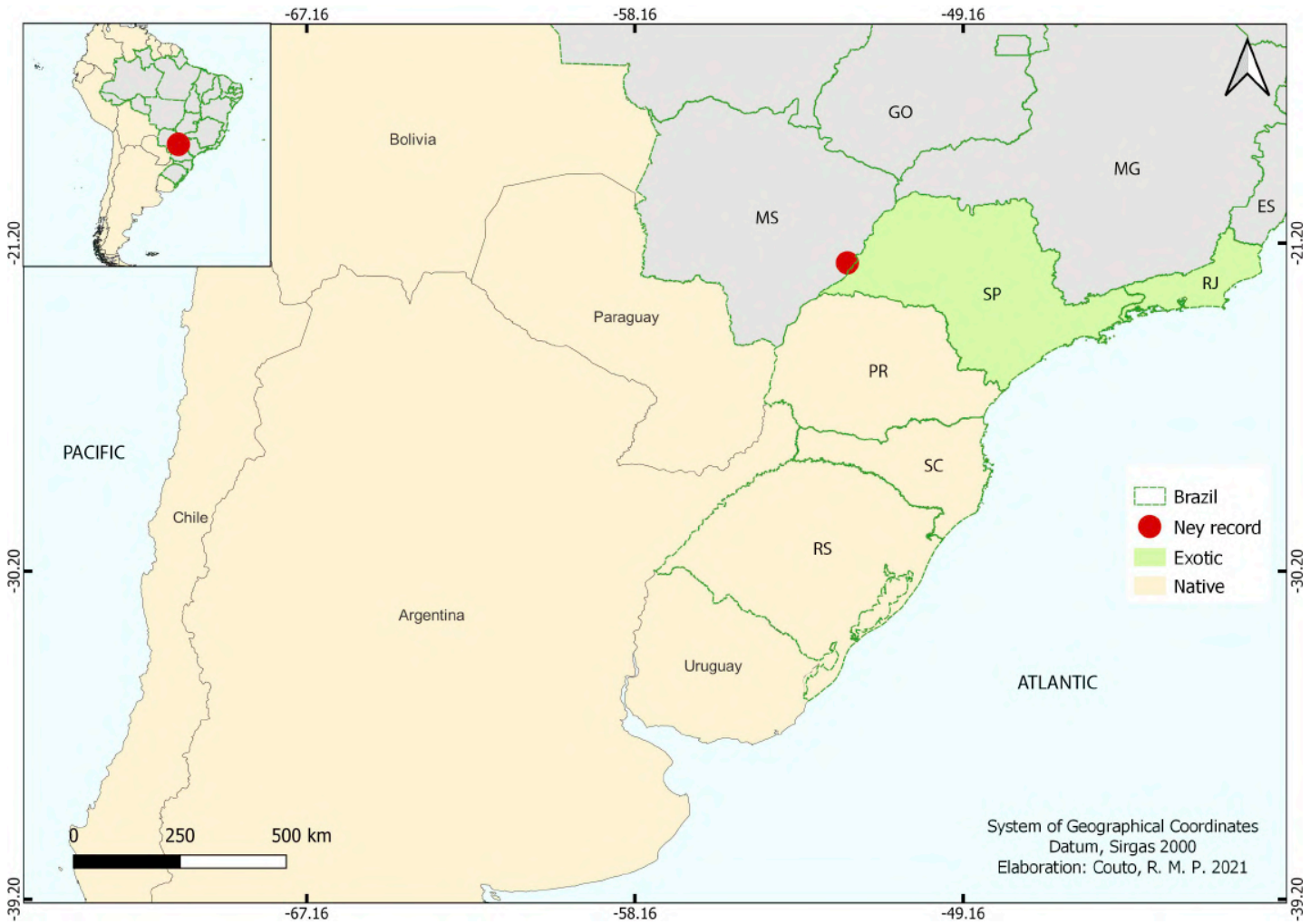

Figure 2. Distribution of Myocastor coypus in South America. Countries in Latin America and Brazilian states where the species is considered native in beige. Brazilian states where the species is considered exotic in green. Red dot indicates place of registration of the present study (Mato Grosso do Sul state).

Table 1. Reports of Myocastor coypus within Brazil microbiológico

\begin{tabular}{c|l|l|l|l|l}
\hline State & City & Reference & State & City & Reference \\
\hline PR & Bom Jesus do Sul & Wolfart et al., 2013 & PR & Curitiba & El-Kouba et al., 2009 \\
PR & Curitiba & GBIF, 2020 & PR & Palotina & Bavaresco et al., 2017 \\
PR & Ouro Verde & Aguiar et al., 2007 & RJ & Três Rios & Bueno, 2013 \\
PR & Quedas do Iguaçu & Juraszek et al., 2014 & RS & Cruz Alta & GBIF, 2020 \\
RS & Cachoeira do Sul & GBIF, 2020 & RS & Mostardas & GBIF, 2020 \\
RS & Cruzeiro do Sul & GBIF, 2020 & RS & Quinta & GBIF, 2020 \\
RS & Pareci Novo & Kasper et al., 2007 & RS & Rio Grande & Espinelli et al., 2014 \\
RS & Rincão Del Rei & GBIF, 2020 & RS & Santa Vitória do Palmar* & GBIF, 2020 \\
RS & Santa Izabel do Sul & Colares et al., 2010 & RS & Tramandaí & GBIF, 2020 \\
RS & Santa Vitória do Palmar & Colares et al., 2010 & SC & Campo Belo do Sul & Kasper et al., 2012 \\
SC & Campeche & GBIF, 2020 & SC & Jaguarura & Cherem et al., 2004 \\
SC & Florianópolis & Cherem et al., 2004 & SC & Rio do Sul & GBIF, 2020 \\
SC & Paulo Lopes & Cherem et al., 2004 & SP & Cubatão & GBIF, 2020 \\
SP & Araraquara & GBIF, 2020 & SP & Guarulhos & GBIF, 2020 \\
SP & Campinas & GBIF, 2020 & SP & Jundiaí & GBIF, 2020 \\
SP & Itatiba & GBIF, 2020 & SP & Limeira & GBIF, 2020 \\
SP & Jaguariúna & GBIF, 2020 & SP & Piracicaba & GBIF, 2020 \\
SP & Pedreira & Bonvicino et al., 2007 & SP & Porto Ferreira & GBIF, 2020 \\
\hline
\end{tabular}

*Fossil records

$\mathrm{PR}=$ Paraná; RJ = Rio de Janeiro; RS = Espírito Santo; SC = Santa Cataria and SP = São 
whether the presence is a result of natural expansion of nearby populations due to changes in the habitats or whether the animals have been introduced and can cause severe impacts on local ecosystems. Given that the record was obtained through an opportunistic way and since in this case we had no license to collect or transport wild animals, we performed a photographic record, and the image is deposited in the UFMS Reference Zoological Collection (ZUFMSMNV00149).

\section{ACKNOWLEDGEMENTS}

We are grateful to Matthijs Strietman for Portuguese to English translation.

\section{CONFLICTS OF INTEREST}

The authors express that there is no conflict of interest.

\section{REFERENCES}

Aguiar, L. M., Ludwig, G., Svoboda, W. K., Hilst, C. L. S., Navarro, I. T., \& Passos, F. C. (2007). Occurrence, local extinction, and conservation of Primates in the corridor of the Upper Paraná River, with notes on other mammals. Revista Brasileira de Zoologia, 24 (4), 898-906. DOI:10.1590/S0101-81752007000400006

Angelici, C., Marini, F, Battisti, C., Bertolino, S., Capizzi, D., \& Monaco, A. (2012). Cumulative impact of rats and coypu on nesting waterbirds: first evidence from a small Mediterranean wetland (central Italy). Vie et Milieu-Life and Environment, 62(3), 137-141. https://www.researchgate.net/publication/258696197_ Cumulative_impact_of_rats_and_coypu_on_nesting_ waterbirds_first_evidences_from_a_small_Mediterranean_ wetland_Central_Italy

Bavaresco, J., Ronnau, M., \& Birck, A. J. (2017). Morfologia do dente do Nutria (Myocastor coypus). Revista Científica de Medicina Veterinária, 29. http://faef.revista.inf.br/imagens_arquivos/arquivos_ destaque/5zOAdrTCwugrVxZ_2017-10-30-19-13-15.pdf

Bertolino, S., \& Ingegno, B. (2009). Modelling the distribution of an introduced species: the coypu Myocastor coypus (Mammalia,Rodentia) in Piedmont region, NW Italy. Italian Journal of Zoology, 76(3), 340-346. DOI:10.1080/11250000903155483

Bonvicino, C. R., D., Andrea, P. S., \& Lemos, E. R. S., (2007). Inventário de pequenos mamíferos não voadores de Pedreira, São Paulo. Boletim da Sociedade Brasileira de Mastozoologia, 49(1), 6-7. https://www.sbmz.org/
wp-content/uploads/2020/06/BolSBMz66_abr2013.pdf

Bonvicino, C. R., Oliveira, J. A., \& D'Andrea, P. S. (2008). Guia dos roedores do Brasil, com chaves para gêneros baseadas em caracteres externos. Centro Pan-Americano de Febre Aftosa - OPAS/OMS. http://www.fiocruz.br/ ioc/media/livro\%20roedores.pdf

Borroto-Páez, R., \& Woods, C. A. (2012). Status and impact of introduced mammals in the West Indies. In $\mathrm{R}$. Borroto-Páez, C. A. Woods, \& F. E. Sergile (Eds), Terrestrial Mammals of the West Indies. Contributions (pp. 241-257). Florida Museum of Natural History and Wacahoota Press. https://www.researchgate.net/ publication/273831021_STATUS_AND_IMPACT_OF_ INTRODUCED_MAMMALS_IN_THE_WEST_INDIES

Bueno, C. (2013). Ocorrência de Myocastor coypus Molina, 1782 no estado do Rio de Janeiro. Boletin da Sociedade Brasileira de Mastozoología, 66, 9-11. https://www.sbmz.org/wp-content/uploads/2020/ 06/BolSBMz66_abr2013.pdf

Carter, J., \& Leonard, B. P. (2002). A review of the literature on the worldwide distribution., spread of, and efforts to eradicate the coypu (Myocastor coypus) Source. Wildlife Society Bulletin, 30(1), 162-175. DOI:10.2307/3784650

Cherem, J. J., Simões-Lopes, P. C., Althoff, S., \& Graipel, M. E. (2004). Lista dos Mamíferos do Estado de Santa Catarina, Sul do Brasil. Mastozoología Neotropical, 11 (2), 151184. https://www.redalyc.org/pdf/457/45711202.pdf

De Vivo, M., Carmignotto, A. P., Gregorin, R., HingstZaher, E., Iack-Ximenes, G. E., Miretzki, M., Percequillo, A. R., Rollo Jr., M. M., Rossi, R. V., \& Taddei, V. A. (2011). Checklist of mammals from São Paulo State, Brazil. Biota Neotropica, 11(1), 1-21. DOI:10.1590/S1676-06032011000500007

El-Kouba, M. M. A. N., Marques, S. M. T., Pilati, C., \& Hamann, W. (2009). Presence of Fasciola hepatica in feral nutria (Myocastor coypus) living in a public park in Brazil, Journal of Zoo and Wildlife Medicine, 40(1), 103-106. DOI:10.1638/2008-0064.1

Genovesi, P., Bacher, S., Kobelt, M., Pascal, M., \& Scalera, R. (2009). Alien mammals of Europe. Chapter 9. Handbook of Alien Species in Europe (pp. 119-128). DOI:10.1007/978-1-4020-8280-1

GBIF. (2020, May). Ocurrence of Myocastor coypus. Global Biodiversity Information Facility. DOI:10.15468/dl.ywwdbu

GISD. (2020). Species profile: Myocastor coypus. Global Invasive Species Database. Retrieved May 29, 2020, from http://www.iucngisd.org/gisd/speciesname/ Myocastor+coypus

Greer, J. K. (1966). Mammals of Malleco Province Chile. Publications of the Museum, Biological Series, 3(2), 49-152.

Guichón, M. L., Doncaster, C. P., \& Cassini, M. H. (2003). Population structure of coypus (Myocastor coypus) in their region of origin and comparison with introduced populations. Journal of Zoology, 261(3), 265-272. DOI:10.1017/S0952836903004187

Guichón, M., Cassini, M. H. (2005). Population parameters of indigenous populations of Myocastor coypus: the effect of hunting pressure. Acta Theriologica, 50(1), 125-132. DOI:10.1007/BF03192625 
Harris, S., Morris, P., \& Yalden, D. (1995). A review of British mammals: population estimates and conservation status of British mammals other than cetaceans. Peterborough: The Joint Nature Conservation Committee. https://www.semanticscholar. org/paper/A-Review-of-British-Mammals\%

3A-Population-Estimates-Harris-Morris/

01eeec9ff62b08af35497a28394fe8e1e2ee10a6

Howerth, E. W., Reeves, A. J., McElveen, M. R., \& Austin, F. W. (1994). Survey for Selected Diseases in Nutria (Myocastor coypus) from Louisiana. Journal of Wildlife Diseases, 30(3), 450-453. DOI:10.7589/0090-3558-30.3.450

Kasper, C. B., Bastazini, V. A. G., Soares, J. B. G., \& Freitas, T. R. O. (2012). Abundance of Conepatus chinga (Carnivora, Mephitidae) and other medium-sized mammals in grasslands of southern Brazil. Iheringia, Série Zoologia, 102(3), 303-310. DOI:10.1590/S007347212012000300009

Lacher, T. E., Mccay S. D., Bianconi G. V., Wolf L. K., Roach N. S., \& Percequillo, A. R. (2020). Conservation status of the order Rodentia of Brazil: taxonomic and biogeographical patterns. Boletim do Museu Paraense Emilio Goeldi. Ciências Naturais, 15(3), 535556. DOI:10.46357/bcnaturais.v15i3.234

Lowe, S., Browne, M., Boudjelas, S., \& De Poorter, M. (2000). 100 of the world's worst invasive alien species: a selection from the global invasive species database (Vol. 12). The Invasive Species Specialist Group (ISSG) a specialist group of the Species Survival Commission (SSC) of the World Conservation Union (IUCN) http://www.issg.org/pdf/ publications/worst_100/english_100_worst.pdf

Ménard, A., Agoulon, A., L'hostis, M., Rondelaud, D., Collard, S., \& Chauvin, A. (2001). Myocastor coypus as a reservoir host of Fasciola hepatica in France. Veterinary Research, 32(5), 499-508. DOI:10.1051/vetres:2001141

Moojen, J. 1952. Os roedores do Brasil. Instituto Nacional do Livro, Biblioteca Científica Brasileira, Série A II. Nowak, R.M. 1999. Walker's mammals of the world (6th ed.). Johns Hopkins University Press.

Oliveira, H. de, Urchei, M. A., \& Fietz, C. R. (2000). Aspectos físicos e socioeconômicos da bacia hidrográfica do rio Ivinhema. Embrapa Agropecuária Oeste-Documentos (INFOTECA-E). https://ainfo.cnptia.embrapa.br/ digital/bitstream/item/65676/1/DOC25-00-ivi.pdf

Oliveira, J. A., \& Bonvicino, C. R. (2006). Ordem Rodentia. In N. R. Reis, A. I. Peracchi, W. A. Pedro, \& Lima, I. P. (Eds.). Mamíferos do Brasil (pp. 347-406). Londrina. http://www.uel.br/pos/biologicas/pages/arquivos/pdf/ Livro-completo-Mamiferos-do-Brasil.pdf

Paglia, A. P., Fonseca, G. A. B. da., Rylands, A. B., Herrmann, G., Aguiar, L. M. S., Chiarello, A. G., Leite, Y. L. R., Costa, L. P., Siciliano, S., Kierulff, M. C. M., Mendes, S. L., Mittermeier, R. A., \& Patton, J. L. (2012). Annotated checklist of Brazilian mammals (2nd ed.). Occasional Papers in Conservation Biology, $6(6)$, 1-82. https://www.researchgate.net/publication/ 288902447_Annotated_checklist_of_Brazilian_mammals

Patton, J. L., Pardiñas U. F. J., \& D'elía G. (Eds.). (2015). Mammals of South America: vol. 2: Rodents. The University of Chicago Press. http://www.biodiversidad.gob.ec/wp-content/uploads/ downloads/2019/08/Patton_2015.pdf

Pott, A., Silva, J. S. V., \& Gomes, E. L. (2014). Características da bacia hidrográfica do rio Ivinhema. Revista GeoPantanal, 9(16), 109-124. https://www.alice.cnptia.embrapa.br/alice/bitstream/ doc/1001229/1/RioIvinhema.pdf

Prigioni, C., Balestrieri, A., \& Remonti, L. (2005). Food habits of the coypu, Myocastor coypus, and its impact on aquatic vegetation in a freshwater habitat of NW Italy. Folia Zoologica-PRAHA-, $54(3), 269-277$. https: //www.ivb.cz/wp-content/uploads/54_269-277.pdf

Scaravelli, D. (2002): Problema Myocastor: considerazioni dell'esperienza ravennate. In R. Petrini, and E. Venturatto (Eds.), Atti del Convegno Nazionale "La gestione delle specie alloctone in Italia: il caso de la nutria e del gambero rosso della Louisiana" (pp. 25-28). Centro di Ricerca, Documentazione e Promozione del Padule di Fuccechio. http://www.zoneumidetoscane.it/sites/default/files/ eventi/extra/libro_2_pdf/Convegno_alloctoni_2002.pdf

Walter, B. M. T. (2006). Fitofisionomias do bioma Cerrado: síntese terminológica e relações florísticas. [Doctoral dissertation, Instituto de Ciencias Biologicas, Universidade de Brasilia]. Repositorio Institucional da UNB. https: //repositorio.unb.br/handle/10482/3086

Wilson, D. E., \& Reeder, D. M. (2005). Mammal species of the world: a taxonomic and geographic reference (Vol. 1). Johns Hopkins University Press. DOI:10.1644/06MAMM-R-422.1

Woods, C. A., Contreras, L., Willner-Chapman, G., \& Whidden, H. P. (1992). Myocastor coypus. Mammalian Species, 398 (1), 1-8. DOI: $10.2307 / 3504182$

Zavattini, J. A. (2009). As chuvas e as massas de ar no estado de Mato Grosso do Sul: estudo geográfico com vista à regionalização climática. Editora UNESP; Cultura Acadêmica. http://hdl.handle.net/11449/109096 